\title{
Identification of emerging Acinetobacter johnsonii virulence and antibiotic resistance genes associated with high mortality in cultured Oreochromis niloticus
}

Hiam Elabd ${ }^{1}$, Abd El-latif A M ${ }^{1 *}$, Adel Shaheen ${ }^{1}$ and Aya Matter ${ }^{1}$

1 Department of Aquatic animals Diseases and Management, Faculty of Veterinary Medicine, Benha University, Toukh, 13736, Egypt.

* Correspondence: E-mail: ashrafmohamed28@yahoo.com;

Tel.: +2 013 2460640; Fax: +2 0132463074.

Received: April 29, 2020; Accepted: May.20, 2020 published: 2020 Vol.10 (2):19-33

\section{ABSTRACT}

The present study was planned to investigate the causative agent of Oreochromis niloticus summer mortality that resulted in significant economic losses in Port Said Governorate, Egypt during 2017. Many bacterial isolates were identified, among which Acinetobacter johnsonii has been selected to be the focus of the current study. Acinetobacter johnsonii_Egy was isolated and identified using the analytical profile index (API) $20 \mathrm{E}$, sequencing $16 \mathrm{~S}$ ribossomal RNA gene fragment and phylogenetic analysis. A drug resistance evaluation revealed that A. johnsonii was resistant to ampicillin, gentamicin, lincomycin, nalidixic acid, tetracycline, and oxytetracycline among the tested antibiotics. Experimental infection was performed and challenged fish revealed similar clinical signs as seen in naturally infected ones. The disease appears to be highly infectious and lethal, causing $100 \%$ cumulative mortality during experimental infections. Virulence genes (fimH, traT, and $i u t A$ ) and antibiotic resistance genes (qacEDl, qnrS, sull, $d f r A$, and aadAl) presence was confirmed in the A. johnsonii_Egy isolate.

In conclusion, A. johnsonii is highly infectious to $O$. niloticus and might have a great influence on transfer of the antibiotic resistance in aquaculture. According to the available knowledge, this study is first to report $A$. johnsonii as emerging opportunistic pathogen in the Egyptian Nile tilapia (in Port Said).

Keywords: Acinetobacter johnsonii_Egy; O. niloticus; Antibiotic susceptibility; Virulence. 


\section{INTRODUCTION}

Acinetobacter bacteria have been extensively identified as Gram-negative, non-motile, non-fermentative, catalase positive, and oxidase negative rods. Most strains require incubation temperatures of 20 to $37^{\circ} \mathrm{C}$. Colony colors vary from translucent, faint yellow, or grayish-white (Doughari et al., 2011).

Acinetobacter are generally distributed in sewage, soil, food, and water (Huddedar et al., 2002), one of the normal digestive tract flora in marine animals (Chang $\boldsymbol{e t}$ al., 2015) and could be considered as an important emerging nosocomial pathogen (Vahdani et al., 2011).

Initially, Acinetobacter was isolated from human patients and identified as the causative agent of many types of infections, including meningitis, septicemia, and urinary, genital, respiratory tract, and wound infections (Singh et al., 2013). After that, in April 2016, few reports showed up reporting Acinetobacter johnsonii infection in the cultured blunt snout bream Megalobrama amblycephala, common carp Cyprinus carpio and rainbow trout Oncorhynchus mykiss (Pękala-Safińska, 2018); even though there is little information on the role of Acinetobacter in fish pathology and disease occurrence. A. johnsonii appears to be highly pathogenic, causing $>80 \%$ mortality and causing hemorrhaging all over fish skin and fins (Cao et al., 2017). Significant A. johnsonii drug resistance to many antibiotics compounds has previously been reported (Blossom and Srinivasan, 2008; Nowak et al., 2010). This resistance in turn, has caused a decrease in available drug options for treatment (Park et al., 2009).

The aim of the current investigation was to identify Acinetobacter spp. isolated from diseased Oreochromis niloticus in order to evaluate this species' pathogenicity through experimental infection and determine its susceptibility to the most commonly used antimicrobial agents.

\section{MATERIALS AND METHODS}

\section{Fish collection and sampling}

A total of 80 naturally infected $O$. niloticus with average body weight $200 \pm 15 \mathrm{~g}$ were collected from different private fish farms in Port Said Governorate, Egypt during the 2017summer infection/mortality season. Clinically diseased and newly deceased fish were immediately transferred cooled in ice boxes and without direct contact with ice to the laboratory of the department of Aquatic Animals Diseases and Management, Benha University. Clinical, postmortem, and bacteriological examinations were carried out according to Austin and Austin (2007). 


\section{Bacteriological Examination}

Under complete aseptic conditions, samples were taken from skin lesions, gills, liver, kidneys, spleen, brain, and intestines of the clinically diseased fish, inoculated onto Brain Heart Infusion broth (BHIB), incubated at $28^{\circ} \mathrm{C}$ for $24 \mathrm{hrs}$ and then streaked over Brain Heart Infusion agar (BHIA). They were then incubated at $28^{\circ} \mathrm{C}$ for another $24 \mathrm{hrs}$ (Tonguthai et al., 1999). Separate colonies were later picked up and stored in $15 \%$ glycerol $(15 \mathrm{ml}$ glycerol in $85 \mathrm{ml}$ tryptic soy broth [TSB] supplement) at $-80^{\circ} \mathrm{C}$ according to Hollander and Nell (1954). Gram staining and motility testing were performed according to Cruickshank et al. (1975). Isolate was identified biochemically by streaking bacterial colonies over TSA, incubated at $28^{\circ} \mathrm{C}$ for $24 \mathrm{hrs}$, and then identified at the genus level using API $20 \mathrm{E}$ strips (Biomerieux, France). Biochemical profiling was done according to catalogue instructions in order to identify the isolated bacteria (Ottaviani et al., 2006).

\section{Molecular characterization}

Using the QIAamp DNA Mini kit (Qiagen, Germany) according to the company's protocol, DNA was extracted from isolated bacteria that had been previously identified using the API $20 \mathrm{E}$ with a $94 \%$ probability rate. DNA concentrations and purity were measured via spectrophotometry and stored at $-20^{\circ} \mathrm{C}$ until use. Primers used in polymerase chain reaction (PCR) amplifications were obtained from (Metabion, Germany), and reaction conditions are listed in Table 1. The amplification reaction was carried out in an applied biosystem 2720 thermal cycler according to the company's protocol. PCR products were analyzed by electrophoresis and visualized by ultraviolet (UV) transillumination. Sequences were analyzed using CLUSTAL W multiple sequence alignment program, version 1.83, which was designed by Thompson et $\mathbf{a l}$. (1984), and a phylogenetic analysis was done using MEGA6 according to Tamura et al. (2013).

\section{Antibiogram}

The antibiogram profile of Acinetobacter johnsonii was constructed according to National Committee for Clinical Laboratory Standard (NCCLS) against eight antibiotic agents (Oxoid, UK) following same procedures of (El Latif et al., 2019), namely gentamycin $10 \mu \mathrm{g}$, ampicillin $10 \mu \mathrm{g}$, nalidixic acid $30 \mu \mathrm{g}$, lincomycin $10 \mu \mathrm{g}$, tetracycline $30 \mu \mathrm{g}$, ofloxacillin $10 \mu \mathrm{g}$, oxytetracycline $30 \mu \mathrm{g}$, and sulfamethoxazoletrimethoprim $25 \mu \mathrm{g}$. The isolate was grown overnight on Muller Hinton broth at $28{ }^{\circ} \mathrm{C}$ and then spread on Muller Hinton Agar plates, then incubated at $28{ }^{\circ} \mathrm{C}$ for $24 \mathrm{hrs}$. 


\section{Assessment of Acinetobacter johnsonii _ Egy virulence}

The intensity of $A$. johnsonii virulence was evaluated using a specified protocol. A total of 50 O. niloticus fish with average body weight of $30 \pm 5.0$ $\mathrm{g}$ were procured from a private fish farm and divided into five groups of 10 fish each in glass tanks. The first four groups were intraperitoneally injected with $0.2 \mathrm{ml}$ of $A$. johnsonii bacterial cell suspension at different concentrations of 0.3, 0.6, 1.2 and $1.8 \times 10^{8} \mathrm{cfu} / \mathrm{ml}$ according to Abbass et al. (2010). The fifth group was used as the control (inoculated with sterile phosphate buffer saline [PBS]). Feeding was done twice daily at a rate of $3 \%$ of the fish's body weight and water conditions were kept at (water temperature $25 \pm 0.5^{\circ} \mathrm{C}$, dissolved oxygen $6 \pm 0.2 \mathrm{mg} / \mathrm{L}$, ammonia concentration was $0.53 \pm 0.07 \mathrm{mg} / \mathrm{L}$ and $\mathrm{pH}$ was $7 \pm 0.4$ ), Clinical signs and mortality rates for all groups were recorded daily for seven days post injection, and Koch's postulates were achieved through re-isolation and identification of bacterial strains as previously described.

Authors followed Benha University's guidelines for the use and care of laboratory animals.

\section{Detection of virulence and antibiotic resistance genes}

Primers are presented in Table 1 . The reaction was performed as previously described using an Applied biosystem 2720 thermal cycler according to the company's protocol.

\section{RESULTS}

\section{Clinical examination}

The external clinical signs of diseased $O$. niloticus appeared as loss of appetite, scales loss, darkness, and hemorrhagic patches all over the body. The internal examination revealed congestion of all the internal organs, especially kidneys and liver (Fig.1).

\section{Isolation and identification of the bacteria}

The isolated colonies were round, colorless, convex, and 1-2 mm on TSA medium. They were also gram-negative, coccobacilli to rod-shaped and non-motile bacteria.

Biochemical results using the API 20E kit showed positive results for $\beta$ galactosidase, lysine decarboxylase, arginine dihydrolase, ornithine decarboxylase, citrate utilisation, acetoin production, gelatin hydrolysis, and tryptophan deamination. The isolate showed biochemical characteristics resembling A. johnsonii. 
Table 1 Primers sequences, target genes, amplicon sizes and cycling conditions.

\begin{tabular}{|c|c|c|c|c|c|c|c|c|}
\hline \multirow{2}{*}{$\begin{array}{c}\text { Target } \\
\text { gene }\end{array}$} & \multirow[t]{2}{*}{ Primers sequences } & \multirow{2}{*}{$\begin{array}{l}\text { Amplified } \\
\text { segment } \\
\text { (bp) }\end{array}$} & \multirow{2}{*}{$\begin{array}{c}\text { 1ry } \\
\text { denaturation }\end{array}$} & \multicolumn{3}{|c|}{ Amplification (35 cycles) } & \multirow{2}{*}{$\begin{array}{c}\text { Final } \\
\text { extensio } \\
n\end{array}$} & \multirow[t]{2}{*}{ Reference } \\
\hline & & & & $\begin{array}{c}2^{\text {nd }} \\
\text { denaturation }\end{array}$ & Annealing & Extension & & \\
\hline \multirow{2}{*}{$\begin{array}{c}16 S \\
r R N A\end{array}$} & AGAGTTTGATCMTGGCTCAG & \multirow[t]{2}{*}{1485} & \multirow{2}{*}{$\begin{array}{l}94^{\circ} \mathrm{C} \\
5 \mathrm{~min} .\end{array}$} & \multirow{2}{*}{$\begin{array}{l}94^{\circ} \mathrm{C} \\
30 \mathrm{sec} .\end{array}$} & \multirow{2}{*}{$\begin{array}{l}56^{\circ} \mathrm{C} \\
1 \mathrm{~min} .\end{array}$} & \multirow{2}{*}{$\begin{array}{c}72^{\circ} \mathrm{C} \\
1.2 \mathrm{~min}\end{array}$} & \multirow{2}{*}{$\begin{array}{c}72^{\circ} \mathrm{C} \\
12 \mathrm{~min}\end{array}$} & \multirow{2}{*}{ Lagacéet al., 2004} \\
\hline & TACGGYTACCTTGTTACGACTT & & & & & & & \\
\hline \multicolumn{9}{|c|}{ Virulence genes } \\
\hline \multirow{2}{*}{ fimH } & TGCAGAACGGATAAGCCGTGG & \multirow[t]{2}{*}{508} & \multirow{2}{*}{$\begin{array}{l}94^{\circ} \mathrm{C} \\
5 \mathrm{~min} .\end{array}$} & \multirow{2}{*}{$\begin{array}{c}94^{\circ} \mathrm{C} \\
30 \mathrm{sec} .\end{array}$} & \multirow{2}{*}{$\begin{array}{c}50^{\circ} \mathrm{C} \\
40 \mathrm{sec} .\end{array}$} & \multirow{2}{*}{$\begin{array}{l}72^{\circ} \mathrm{C} \\
45 \mathrm{sec} .\end{array}$} & \multirow{2}{*}{$\begin{array}{c}72^{\circ} \mathrm{C} \\
10 \mathrm{~min} .\end{array}$} & \multirow{2}{*}{$\begin{array}{l}\text { Ghanbarpour and } \\
\text { Salehi, } 2010\end{array}$} \\
\hline & GCAGTCACCTGCCCTCCGGTA & & & & & & & \\
\hline \multirow[t]{2}{*}{ TraT } & GATGGCTGAACCGTGGTTATG & \multirow[t]{2}{*}{307} & \multirow{2}{*}{$\begin{array}{l}94^{\circ} \mathrm{C} \\
5 \mathrm{~min} .\end{array}$} & \multirow{2}{*}{$\begin{array}{l}94^{\circ} \mathrm{C} \\
30 \mathrm{sec} .\end{array}$} & \multirow{2}{*}{$\begin{array}{c}55^{\circ} \mathrm{C} \\
30 \mathrm{sec} \\
\end{array}$} & \multirow{2}{*}{$\begin{array}{l}72^{\circ} \mathrm{C} \\
30 \mathrm{sec} \\
\end{array}$} & \multirow{2}{*}{$\begin{array}{l}72^{\circ} \mathrm{C} \\
7 \mathrm{~min} .\end{array}$} & \multirow{2}{*}{$\begin{array}{l}\text { Kaipainen et al., } \\
2002\end{array}$} \\
\hline & CACACGGGTCTGGTATTTATGC & & & & & & & \\
\hline \multirow[t]{2}{*}{ iutA } & GGCTGGACATGGGAACTGG & 300 & $94^{\circ} \mathrm{C}$ & $94^{\circ} \mathrm{C}$ & $63^{\circ} \mathrm{C}$ & $72^{\circ} \mathrm{C}$ & $72^{\circ} \mathrm{C}$ & Yaguchi et al., 2007 \\
\hline & CGTCGGGAACGGGTAGAATCG & & 5 min. & $30 \mathrm{sec}$. & $30 \mathrm{sec}$ & $30 \mathrm{sec}$ & 7 min. & \\
\hline papC & TGATATCACGCAGTCAGTAGC & 501 & $94^{\circ} \mathrm{C}$ & $94^{\circ} \mathrm{C}$ & $58^{\circ} \mathrm{C}$ & $72^{\circ} \mathrm{C}$ & $72^{\circ} \mathrm{C}$ & Wen-jieet al., 2008 \\
\hline & CCGGCCATATTCACATAA & & $5 \mathrm{~min}$. & $30 \mathrm{sec}$. & $40 \mathrm{sec}$ & $45 \mathrm{sec}$ & $10 \mathrm{~min}$. & \\
\hline Antibio & c resistance genes & & & & & & & \\
\hline $\begin{array}{c}\text { QacE } \\
\text { D1 }\end{array}$ & $\begin{array}{c}\text { TAA GCC CTA CAC AAA TTG } \\
\text { GGA GAT AT }\end{array}$ & 362 & $\begin{array}{l}94^{\circ} \mathrm{C} \\
5 \mathrm{~min} .\end{array}$ & $\begin{array}{c}94^{\circ} \mathrm{C} \\
30 \mathrm{sec} .\end{array}$ & $\begin{array}{c}58^{\circ} \mathrm{C} \\
40 \mathrm{sec}\end{array}$ & $\begin{array}{l}72^{\circ} \mathrm{C} \\
40 \mathrm{sec}\end{array}$ & $\begin{array}{c}72^{\circ} \mathrm{C} \\
10 \mathrm{~min} .\end{array}$ & $\begin{array}{l}\text { Chuanchuen et al., } \\
2007\end{array}$ \\
\hline & $\begin{array}{c}\text { GCC TCC GCA GCG ACT TCC } \\
\text { ACG }\end{array}$ & & & & & & & \\
\hline$q n r S$ & ACGACATTCGTCAACTGCAA & 417 & $94^{\circ} \mathrm{C}$ & $94^{\circ} \mathrm{C}$ & $55^{\circ} \mathrm{C}$ & $72^{\circ} \mathrm{C}$ & $72^{\circ} \mathrm{C}$ & Randall et al. 2004 \\
\hline & TAAATTGGCACCCTGTAGGC & & 5 min. & $30 \mathrm{sec}$. & $40 \mathrm{sec}$ & $45 \mathrm{sec}$ & $10 \mathrm{~min}$. & \\
\hline Sull & CGGCGTGGGCTACCTGAACG & 433 & $94^{\circ} \mathrm{C}$ & $94^{\circ} \mathrm{C}$ & $60^{\circ} \mathrm{C}$ & $72^{\circ} \mathrm{C}$ & $72^{\circ} \mathrm{C}$ & Ibekweet al., 2011 \\
\hline & GCCGATCGCGTGAAGTTCCG & & $5 \mathrm{~min}$. & $30 \mathrm{sec}$. & $40 \mathrm{sec}$ & $45 \mathrm{sec}$ & $10 \mathrm{~min}$. & \\
\hline$d f r A$ & $\begin{array}{c}\text { TGGTAGCTATATCGAAGAATGG } \\
\text { AGT }\end{array}$ & 425 & $\begin{array}{l}94^{\circ} \mathrm{C} \\
5 \mathrm{~min} .\end{array}$ & $\begin{array}{l}94^{\circ} \mathrm{C} \\
30 \mathrm{sec} .\end{array}$ & $\begin{array}{l}60^{\circ} \mathrm{C} \\
40 \mathrm{sec}\end{array}$ & $\begin{array}{l}72^{\circ} \mathrm{C} \\
45 \mathrm{sec}\end{array}$ & $\begin{array}{l}72^{\circ} \mathrm{C} \\
10 \mathrm{~min}\end{array}$ & Grape et al., 2007 \\
\hline & $\begin{array}{l}\text { TATGTTAGAGGCGAAGTCTTGG } \\
\text { GTA }\end{array}$ & & & & & & & \\
\hline Aadal & TATCAGAGGTAGTTGGCGTCAT & 484 & $94^{\circ} \mathrm{C}$ & $94^{\circ} \mathrm{C}$ & $54^{\circ} \mathrm{C}$ & $72^{\circ} \mathrm{C}$ & $72^{\circ} \mathrm{C}$ & Randall et al. 2004 \\
\hline
\end{tabular}


Hiam et al., 2020; Egy. J. Aquac 10(2):19-33

\begin{tabular}{|c|c|c|c|c|c|c|c|c|}
\hline & $\begin{array}{c}\text { GTTCCATAGCGTTAAGGTTTCA } \\
\text { TT }\end{array}$ & & 5 min. & $30 \mathrm{sec}$. & $40 \mathrm{sec}$ & $45 \mathrm{sec}$ & 10 min. & \\
\hline \multirow[t]{2}{*}{ Kan } & GTGTTTATGGCTCTCTTGGTC & \multirow[t]{2}{*}{621} & \multirow[t]{2}{*}{$\begin{array}{l}94^{\circ} \mathrm{C} \\
5 \text { min. }\end{array}$} & \multirow[t]{2}{*}{$\begin{array}{l}94^{\circ} \mathrm{C} \\
30 \mathrm{sec} .\end{array}$} & \multirow[t]{2}{*}{$\begin{array}{l}54^{\circ} \mathrm{C} \\
40 \mathrm{sec}\end{array}$} & \multirow[t]{2}{*}{$\begin{array}{l}72^{\circ} \mathrm{C} \\
45 \mathrm{sec}\end{array}$} & \multirow[t]{2}{*}{$\begin{array}{l}72^{\circ} \mathrm{C} \\
10 \mathrm{~min}\end{array}$} & \multirow[t]{2}{*}{ Franaet al., 2001} \\
\hline & CCGTGTCGTTCTGTCCACTCC & & & & & & & \\
\hline \multirow{2}{*}{$\begin{array}{c}\text { blaND } \\
M\end{array}$} & GGTTTGGCGATCTGGTTTTC & \multirow[t]{2}{*}{621} & \multirow{2}{*}{$\begin{array}{l}94^{\circ} \mathrm{C} \\
5 \mathrm{~min} .\end{array}$} & \multirow{2}{*}{$\begin{array}{l}94^{\circ} \mathrm{C} \\
30 \mathrm{sec} .\end{array}$} & \multirow{2}{*}{$\begin{array}{l}52^{\circ} \mathrm{C} \\
40 \mathrm{sec}\end{array}$} & \multirow{2}{*}{$\begin{array}{l}72^{\circ} \mathrm{C} \\
45 \mathrm{sec}\end{array}$} & \multirow{2}{*}{$\begin{array}{l}72^{\circ} \mathrm{C} \\
10 \mathrm{~min} .\end{array}$} & \multirow{2}{*}{$\begin{array}{l}\text { Nordmannet al., } \\
2011\end{array}$} \\
\hline & CGGAATGGCTCATCACGATC & & & & & & & \\
\hline \multirow{2}{*}{$\begin{array}{c}\text { blaTE } \\
M\end{array}$} & ATCAGCAATAAACCAGC & \multirow[t]{2}{*}{516} & \multirow{2}{*}{$\begin{array}{l}94^{\circ} \mathrm{C} \\
5 \mathrm{~min} .\end{array}$} & \multirow{2}{*}{$\begin{array}{l}94^{\circ} \mathrm{C} \\
30 \mathrm{sec} .\end{array}$} & \multirow{2}{*}{$\begin{array}{l}54^{\circ} \mathrm{C} \\
40 \mathrm{sec}\end{array}$} & \multirow{2}{*}{$\begin{array}{l}72^{\circ} \mathrm{C} \\
45 \mathrm{sec}\end{array}$} & \multirow{2}{*}{$\begin{array}{l}72^{\circ} \mathrm{C} \\
10 \mathrm{~min} .\end{array}$} & \multirow[t]{2}{*}{ Colom et al., 2003} \\
\hline & CCCCGAAGAACGTTTTC & & & & & & & \\
\hline \multirow{2}{*}{$\begin{array}{c}\text { TetA }(A \\
)\end{array}$} & GGTTCACTCGAACGACGTCA & \multirow[t]{2}{*}{576} & \multirow{2}{*}{$\begin{array}{l}94^{\circ} \mathrm{C} \\
5 \mathrm{~min} .\end{array}$} & \multirow{2}{*}{$\begin{array}{l}94^{\circ} \mathrm{C} \\
30 \mathrm{sec} .\end{array}$} & \multirow{2}{*}{$\begin{array}{l}50^{\circ} \mathrm{C} \\
40 \mathrm{sec}\end{array}$} & \multirow{2}{*}{$\begin{array}{r}72^{\circ} \mathrm{C} \\
45 \mathrm{sec}\end{array}$} & \multirow{2}{*}{$\begin{array}{l}72^{\circ} \mathrm{C} \\
10 \mathrm{~min} .\end{array}$} & \multirow[t]{2}{*}{ Randall et al. 2004} \\
\hline & CTGTCCGACAAGTTGCATGA & & & & & & & \\
\hline \multirow[t]{2}{*}{$a a d B$} & GAGCGAAATCTGCCGCTCTGG & \multirow[t]{2}{*}{319} & \multirow{2}{*}{$\begin{array}{l}94^{\circ} \mathrm{C} \\
5 \text { min. }\end{array}$} & \multirow{2}{*}{$\begin{array}{l}94^{\circ} \mathrm{C} \\
30 \mathrm{sec} .\end{array}$} & $58^{\circ} \mathrm{C}$ & $72^{\circ} \mathrm{C}$ & $72^{\circ} \mathrm{C}$ & Franaet al., 2001 \\
\hline & CTGTTACAACGGACTGGCCGC & & & & & $40 \mathrm{sec}$ & $10 \mathrm{~min}$. & \\
\hline floR & TTTGGWCCGCTMTCRGAC & 494 & $94^{\circ} \mathrm{C}$ & $94^{\circ} \mathrm{C}$ & $50^{\circ} \mathrm{C}$ & $72^{\circ} \mathrm{C}$ & $72^{\circ} \mathrm{C}$ & Doublet et al., 2003 \\
\hline & SGAGAARAAGACGAAGAAG & & 5 min. & $30 \mathrm{SE}$ & $40 \mathrm{sec}$ & $45 \mathrm{sec}$ & $10 \mathrm{~min}$. & \\
\hline$m p h A$ & GTGAGGAGGAGCTTCGCGAG & 403 & $94^{\circ} \mathrm{C}$ & $94^{\circ} \mathrm{C}$ & $58^{\circ} \mathrm{C}$ & $72^{\circ} \mathrm{C}$ & $72^{\circ} \mathrm{C}$ & Nguyen et al., 2009 \\
\hline & TGCCGCAGGACTCGGAGGTC & & 5 min. & $30 \mathrm{sec}$. & $40 \mathrm{sec}$ & $40 \mathrm{sec}$ & $10 \mathrm{~min}$. & \\
\hline ermB & CATTTAACGACGAAACTGGC & 425 & $94^{\circ} \mathrm{C}$ & $94^{\circ} \mathrm{C}$ & $51^{\circ} \mathrm{C}$ & $72^{\circ} \mathrm{C}$ & $72^{\circ} \mathrm{C}$ & Nguyen et al., 2009 \\
\hline & GGAACATCTGTGGTATGGCG & & J & $30 \mathrm{se}$ & $40 \mathrm{sec}$ & $4 \mathrm{~J} \mathrm{Sec}$ & & \\
\hline
\end{tabular}




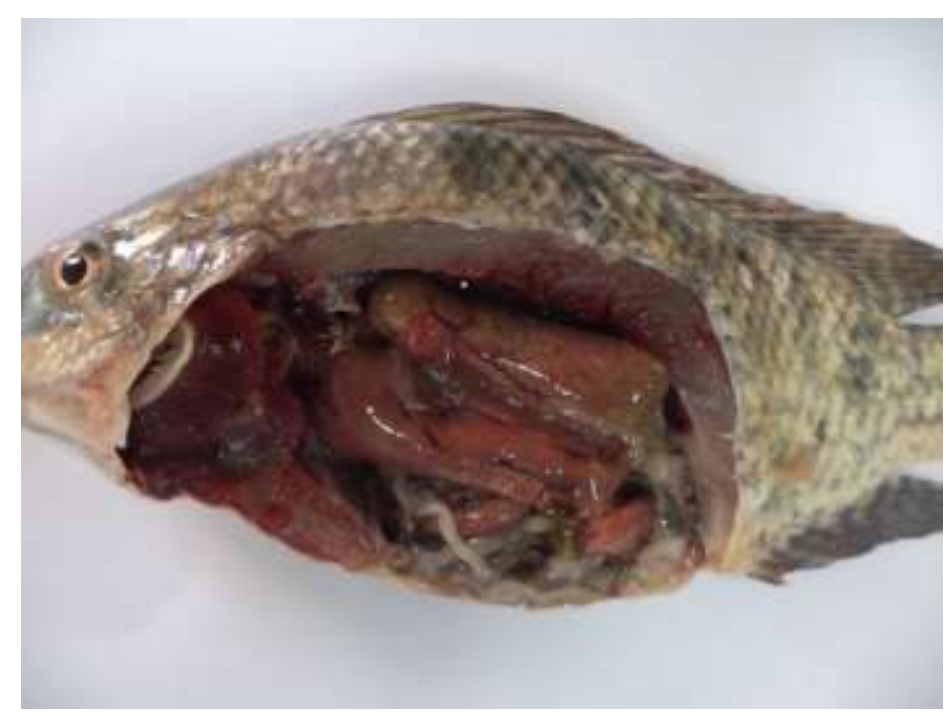

Fig. 1. Oreochromis niloticus infected with Aceietobacter johnsonii showing congestion of all internal organs, especially kidney and liver (asterisk).
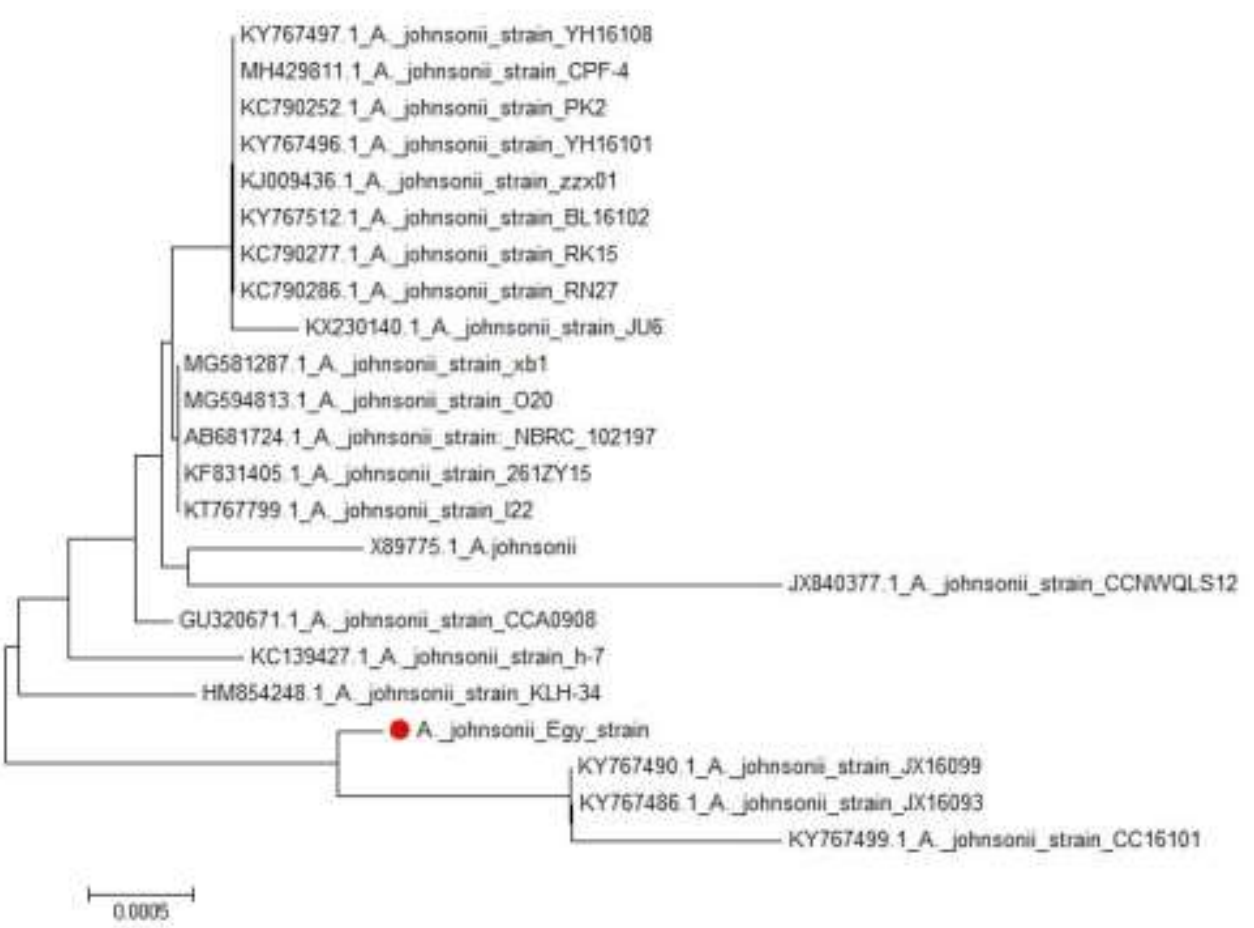

Fig.2. Phylogenetic tree for $16 S r R N A$ partial sequences that was generated using maximum likelihood, neighbor joining and maximum parsimony in MEGA6. Phylogenetic tree showed clear clustering of the isolated Egyptian strain ( $A$. johnsonii_Egy_strain) with different $A$. johnsonii strains uploaded from GenBank. 


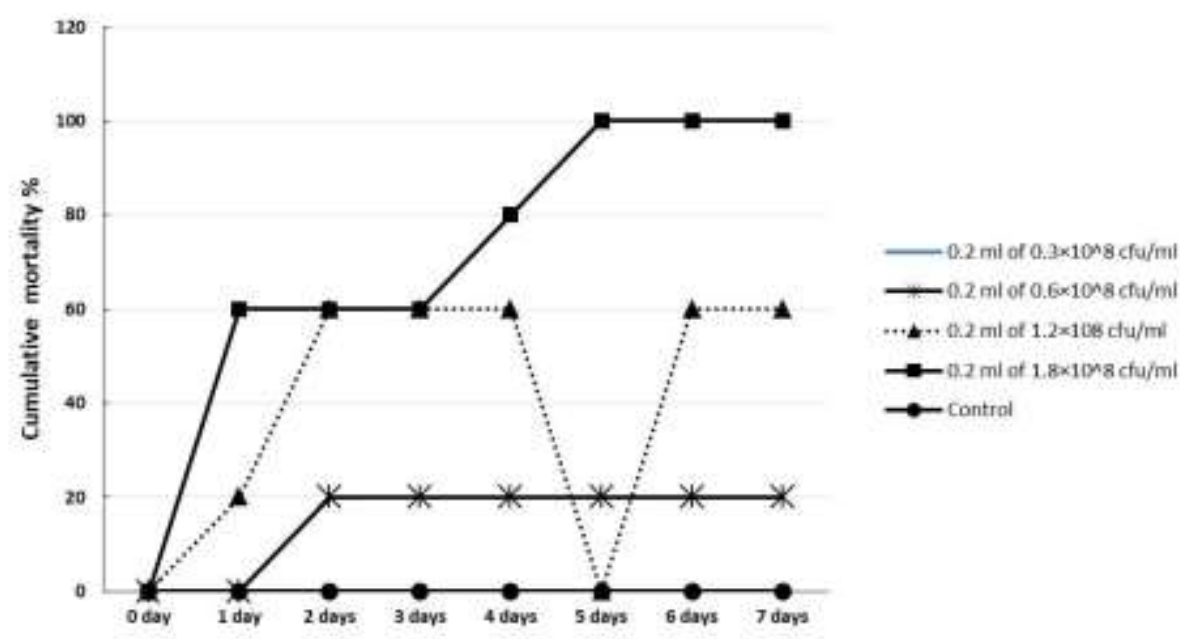

Fig.3. Daily cumulative mortality of experimental intra-peritonealy challenged Nile tilapia fish with $0.2 \mathrm{ml}$ Acinetobacter johnsonii at $0.3,0.8,1.2$ and $1.8 \times 10^{8} \mathrm{cfu} / \mathrm{ml}$ cells/ml/fish. Number in brackets represents dose of bacterial cells and fish were observed for 7 days.

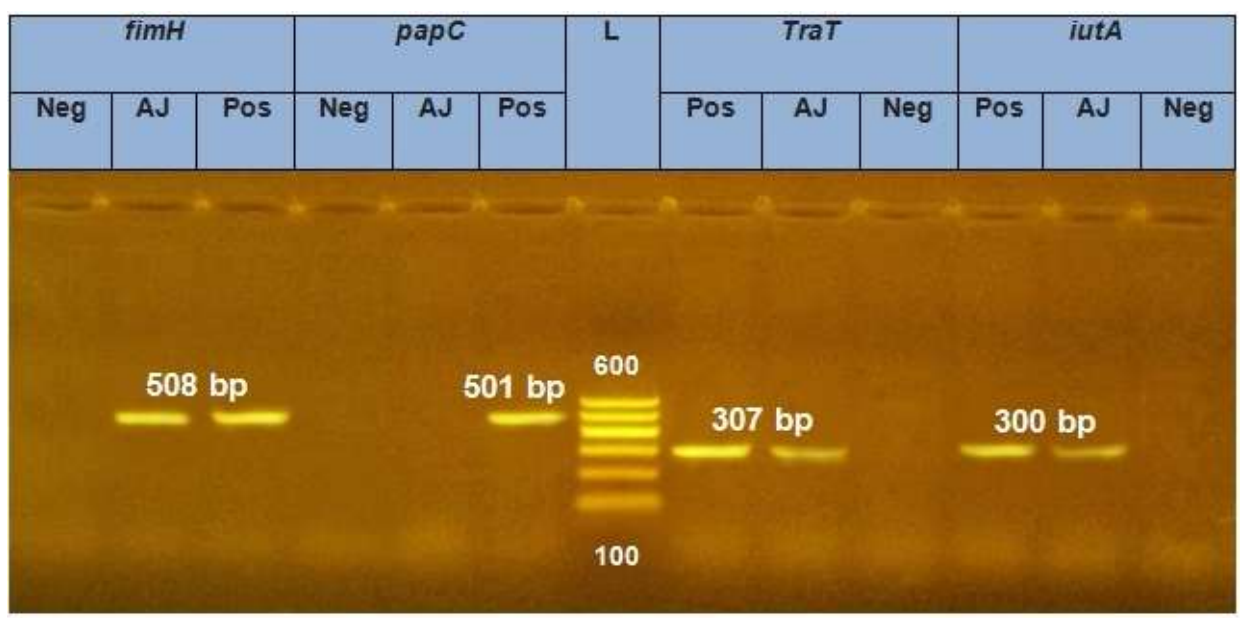

Fig.4. Ethidium bromide staining of a $2 \%$ agarose gel with polymerase chain reaction (PCR) products showing virulence genes (fimH, TraT, and iutA) +ve samples of 508, 300, and $306 \mathrm{bp}$ PCR products, respectively, from bacterial culture. L represents a $600 \mathrm{bp}$ DNA ladder used as a sizing standard. 


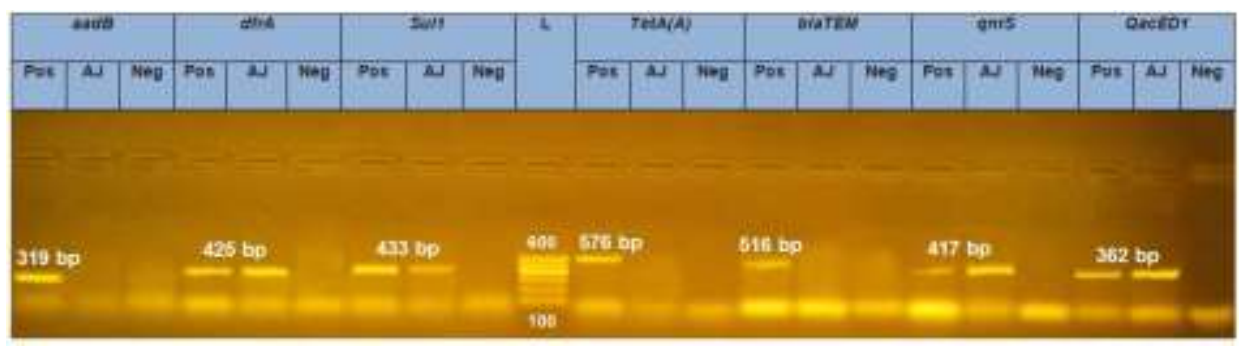

Fig.5. Ethidium bromide staining of a $2 \%$ agarose gel with PCR products showing antibiotic resistance genes (Aadal) +ve samples of 484 and 494 bp PCR products, respectively, from bacterial culture. L represents a 600 bp DNA ladder used as a sizing standard.

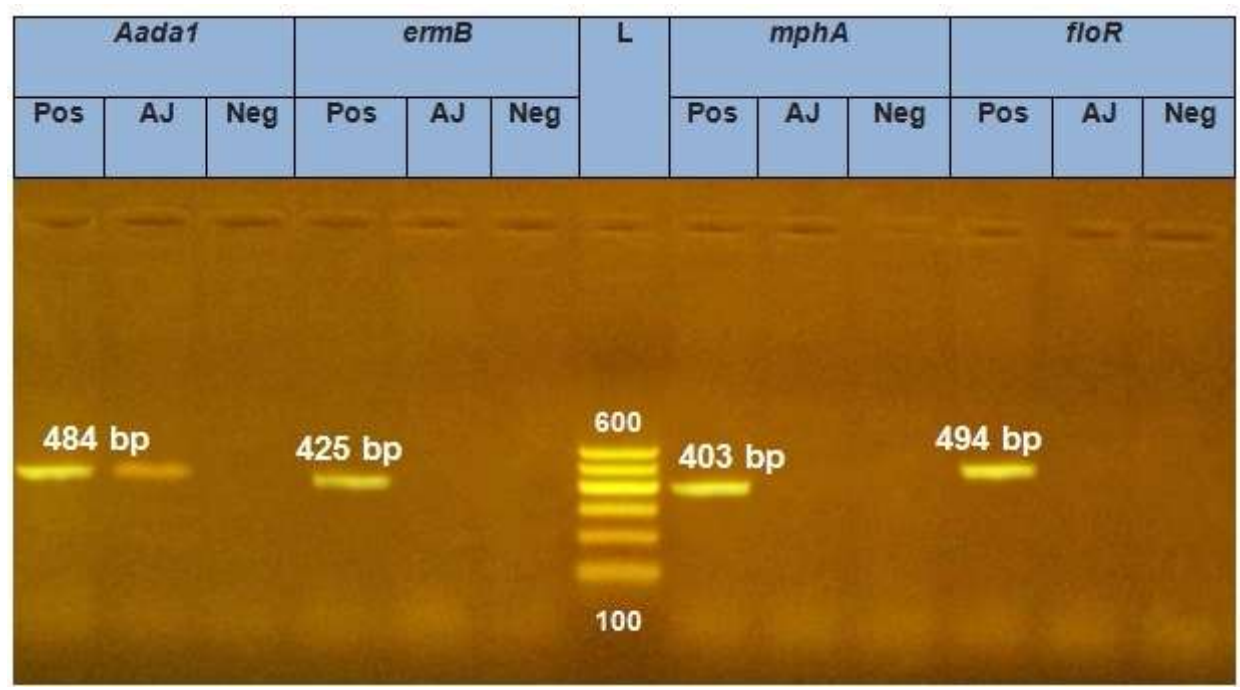

Fig.6. Antibiotic resistance genes (dfrA, Sul1, qnrS, and QacED1) +ve samples of 425, 433,417 , and 362 bp PCR products, respectively. L represents a $600 \mathrm{bp}$ DNA ladder used as a sizing standard.

\section{Molecular characterization}

Sequencing of the PCR product targeting the $16 \mathrm{~S}$ ribosomal RNA (1485bp) showed an identity of $98.2 \%$ to $99.4 \%$ homology between the isolated Egyptian strain (A. johnsonii_Egy, GenBank accession number MK012190) and different A. johnsonii strains uploaded from the gene bank.

\section{Phylogenetic analysis}

The phylogenetic tree showed clear clustering of the isolated Egyptian strain with different $A$. johnsonii strains uploaded from the gene bank (Fig.2). 


\section{Antibiotic susceptibility}

Antibiotic sensitivity test of the isolated A. johnsonii revealed that it was resistant to all tested antibiotics (gentamycin, ampicillin, nalidixic acid, lincomycin, tetracycline, ofloxacillin, oxytetracycline, and sulfamethoxazole- trimethoprim) and only sensitive to ofloxacillin and sulfamethoxazole-trimethoprim.

\section{Experimental infection challenge}

The tested $A$. johnsonii was pathogenic to tilapia juveniles, and the cumulative mortality rate reached $100 \%$ of total injected fishes for $1.8 \times 10^{8}$ $\mathrm{cfu} / \mathrm{ml}$ dose (Figure 3). Clinically infected fish exhibited similar clinical signs and postmortem changes as recorded in naturally infected ones.

\section{Acinetobacter johnsonii_Egy virulence and antibiotic resistance genes assay}

The specific PCR amplifications of virulence and antibacterial sensitivity genes are shown in Figures 4, 5, and 6. Results demonstrate that the virulence genes (fimH, TraT, and iutA) and antibiotic resistance genes (QacED1, qnrS, Sull, dfrA, and Aadal) existed all in the A. johnsonii_Egy isolate, indicating its multidrug resistant property.

\section{DISCUSSION}

Acinetobacter are usually perceived as normal saprophytic microorganisms that are present in aquatic environments and colonized in aquatic animals' skin, gills, and digestive tracts. It constitutes a remarkable example of bacterial emergence, evolving from traditionally harmless organisms toward important pathogenic bacteria, probably related to antibacterial resistance transfer in the aquatic environment. A.johnsonii was isolated from diseased rainbow trout and this considered the first report concerning its pathogenicity in fish species (Kozińska et al., 2014).

The isolated colonies were convex, round, colorless, and 1-2 mm on TSA medium. Also, they were Gram-negative, non-motile coccobacilli to rodshaped bacteria. Similar results were previously recorded by (González et al., 2000; (Kozińska et al., 2014), who reported the same morphological and biochemical characteristics for Acinetobacter isolates. In addition, Gupta et al. (2015) reported that the isolated Acinetobacter spp. were gram-negative and non-fermenters organisms.

In the present study, A. johnsonii was tentatively identified and confirmed through sequencing of the $16 \mathrm{~S}$ rDNA gene fragment and phylogenetic analysis. Pathogenicity was proven by experimental $O$. niloticus infection, and disease-related signs were similar to those observed in naturally 
infected fish, showing darkness and hemorrhagic patches externally plus organ congestion, especially kidney, liver, and spleen internally.

On a molecular basis, the Egyptian isolate (A. johnsonii_Egy, GenBank accession number MK012190) showed 98.2\%-99.4\% homology with different A. johnsonii strains uploaded from GenBank. Similarly, Cao et al. (2017) observed 99\% and 97\% homology in the 16S rRNA gene sequences between the BY3A. johnsonii isolate and other A. johnsonii isolates from the GenBank database. In addition, Kozińska et al. (2014) reported $99.6 \%$ similarity with the isolate K712 to A. junii and A. johnsonii.

Acinetobacter species are well known to develop resistance to a wide variety of antimicrobial agents, which is currently considered an arising risk to aquaculture. Concerning drug resistance, the current results showed resistance to tetracycline, oxytetracycline, and ampicillin among the tested antibiotics, which are commonly used in aquaculture. At the same time, Kozińska et al. (2014) reported that the majority of the tested isolates showed resistance to $\beta$-lactams (ampicilin and amoxicillin) and cephalothin and sensitivity to fluoroquinolones (flumequine, enrofloxacin, and norfloxacin) and gentamycin; however, use of those antibiotics can affect antimicrobial resistance levels of natural aquatic microflora and, therefore, careful use should be considered (Guardabassi et al., 2000). Also, Gupta et al. (2015) revealed that the isolated Acinetobacter spp. were mostly multi-drug resistant.

To our knowledge, the current study is the first report concerning $A$. johnsonii pathogencity and virulence in $O$. niloticus. The results showed that the tested A. johnsonii strain was pathogenic to the Nile tilapia, and mortality reached $100 \%$ of total injected fishes for a $9 \times 10^{8}$ cells $/ \mathrm{ml}$ dose, which is in agreement with previous results obtained by Kozińska $\boldsymbol{e t}$ al. (2014) and Rauta et al. (2011), who studied the pathogenicity of $A$. johnsonii in their respective fishes.

Regarding to the virulence of the isolated bacteria, the amplification of virulence and antibacterial sensitivity genes demonstrated that the virulence genes (fimH, TraT, and iutA) and antibiotic-resistance genes (QacED1, qnrS, Sull, dfrA, and Aadal) were present in all of $A$. johnsonii_Egy isolates, indicating that the isolate is multidrug resistant. Similarly, Montaña et al., (2016) reported several resistance determinants such as strA, strB, ereA and sull that were previously annotated in the Enterobacteriaceae family. 
A disease might be considered emerging when it appears with a new presentation or higher virulence than previously seen. Thus, A. johnsonii can be regarded as an emerging pathogen for farmed O. niloticus in Egypt. Antibiotic use for controlling bacterial fish pathogens and the development of multi-drug resistant microorganisms are currently of great importance, and Acinetobacter sp. are known to transmit antibiotic resistance genes. Therefore, they may be incriminated in transmission of gene resistance in aquatic systems, and further studies are needed regarding Egyptian Acinetobacter sp. pathogenicity, drug resistance, and virulence.

\section{Conflict of interest}

The authors declare no conflict of interests.

\section{Ethical approval}

The authors followed all institutional guidelines for the care and use of animals.

\section{Data Availability}

There is no shared data available.

\section{References}

Austin B, Austin D A (2007). Bacterial fish pathogens, Disease of farmed and wild fish, 4th Ed. Springer Praxis, Godalming.

Abbass, A., Sharifuzzaman, S.M., Austin, B. (2010). Cellular components of probiotics control Yersinia ruckeri infection in rainbow trout, Oncorhynchus mykiss (Walbaum). J. Fish Dis. 33, 31-37. https://doi.org/10.1111/j.1365-2761.2009.01086.x

Blossom D., Srinivasan A (2008). Drug-resistant Acinetobacter baumannii-calcoaceticus complex: an emerging nosocomial pathogen with few treatment options. Infect Dis Clin Pract, 16, 1-3.

Cao, H., Yu, L., Ou, R., Lu, L., Yang, X., Yang, Y. (2017). Acinetobacter johnsonii: an Emerging Pathogen for Cultured Blunt Snout Bream Megalobrama amblycephala.

Chang H. C., Wei Y. F., Dijkshoorn L., Vaneechoutte M., Tang C. T., Chang T. C. (2005). Species-level identification of isolates of the Acinetobacter calcoaceticus-Acinetobacter baumannii complex by sequence analysis of the 16S-23S rRNA gene spacer region. J. Clin. Microbiol. 43, 1632-1639.

Cruickshank, R.; Duguid, J.P.; Marmion, B.R. and swain, R.H. A. (1975): Medical Microbiology, 12th Ed ., Living stone, London, New York, 812-825. 
Doughari, H.J., Ndakidemi, P.A., Human, I.S., Benade, S. (2011). The ecology, biology and pathogenesis of Acinetobacter spp.: an overview. Microbes Environ. 26, 101-112.

El Latif, A.M.A., Elabd, H., Amin, A., Eldeen, A.I.N., Shaheen, A.A. (2019). High mortalities caused by Aeromonas veronii:identification, pathogenicity, and histopathologicalstudies in Oreochromis niloticus. Aquac. Int. 27, 1725-1737. https://doi.org/10.1007/s10499-019-004298

González, C.J., Santos, J.A., García-López, M.L., Otero, A. (2000). Psychrobacters and related bacteria in freshwater fish. J. Food Prot. 63, 315-321. https://doi.org/10.4315/0362-028x-63.3.315

Guardabassi, L., Dalsgaard, A., Raffatellu, M., Olsen, J.E. (2000). Increase in the prevalence of oxolinic acid resistant Acinetobacter spp. observed in a stream receiving the effluent from a freshwater trout farm following the treatment with oxolinic acid-medicated feed. Aquaculture 188, 205 218. https://doi.org/10.1016/S0044-8486(00)00340-9

Gupta, N., Gandham, N., Jadhav, S., Mishra, R.N. (2015). Isolation and identification of Acinetobacter species with special reference to antibiotic resistance. J. Nat. Sci. Biol. Med. 6, 159-162. https://doi.org/10.4103/0976-9668.149116

Hollander, D.H., Nell, E.E. (1954). Improved Preservation of Treponema pallidum and Other Bacteria by Freezing with Glycerol. Appl. Microbiol. 2, 164-170.

Huddedar, S.B., Shete, A.M., Tilekar, J.N., Gore, S.D., Dhavale, D.D., Chopade, B.A. (2002). Isolation, characterization, and plasmid pUPI126-mediated indole-3-acetic acid production in acinetobacter strains from rhizosphere of wheat. Appl. Biochem. Biotechnol. 102103, 21-39.

Kozińska, A., Paździor, E., Pękala, A., Niemczuk, W. (2014). Acinetobacter johnsonii and Acinetobacter lwoffii - the emerging fish pathogens. Bull. Vet. Inst. Pulawy 58, 193-199. https://doi.org/10.2478/bvip-2014-0029

Montaña, S., Schramm, S.T.J., Traglia, G.M., Chiem, K., Parmeciano Di Noto, G., Almuzara, M., Barberis, C., Vay, C., Quiroga, C., Tolmasky, M.E., Iriarte, A., Ramírez, M.S. (2016). The Genetic Analysis of an Acinetobacter johnsonii Clinical Strain Evidenced the Presence of Horizontal Genetic Transfer. PLoS ONE 11. https://doi.org/10.1371/journal.pone.0161528 
Nowak, J., Pacholczyk, A., Petroniec, V., Dziedzicka, B., Zwolska, Z. (2010). [The results of molecular epidemiological investigations in patients infected with strains of the genus Acinetobacter]. Pneumonol. Alergol. Pol. 78, 386-391.

Ottaviani, D., Santarelli, S., Bacchiocchi, S., Masini, L., Ghittino, C., Bacchiocchi, I. (2006). Occurrence and characterization of Aeromonas spp. in mussels from the Adriatic Sea. Food Microbiol. 23, 418-422. https://doi.org/10.1016/j.fm.2005.08.001

Park, Y.K., Peck, K.R., Cheong, H.S., Chung, D.-R., Song, J.-H., Ko, K.S. (2009). Extreme Drug Resistance in Acinetobacter baumannii Infections in Intensive Care Units, South Korea. Emerg. Infect. Dis. 15, 1325-1327. https://doi.org/10.3201/eid1508.080772

Pękala-Safińska, A. (2018). Contemporary Threats of Bacterial Infections in Freshwater Fish. J. Vet. Res. 62, 261-267. https://doi.org/10.2478/jvetres-2018-0037

Rauta, P.R., Kumar, K., Sahoo, P.K. (2011). Emerging new multi-drug resistant bacterial pathogen, Acinetobacter baumannii associated with snakehead Channa striatus eye infection 548-553.

Singh, H., Thangaraj, P., Chakrabarti, A. (2013). Acinetobacter baumannii: A Brief Account of Mechanisms of Multidrug Resistance and Current and Future Therapeutic Management. J. Clin. Diagn. Res. JCDR 7, 2602-2605. https://doi.org/10.7860/JCDR/2013/6337.3626

Tamura K, Stecher G, Peterson D, Filipski A, Kumar S. (2013) MEGA6: Molecular Evolutionary Genetics Analysis version 6.0. Mol Biol Evol 30: 2725-2729. https://doi.org/10.1093/molbev/mst197.

Thompson JD, Higgins DG, Gibson TJ. (1994) CLUSTAL W: improving the sensitivity of progressive multiple sequence alignment through sequence weighting, position-specific gap penalties and weight matrix choice. Nucleic Acids Res 22: 4673-4680.

Tonguthai K, Chinabut S, Somsiri T, Chanratchakool P, Kanchanakhan S. Diagnostic Procedures for Finfish Diseases. Aquatic Animal Health Research Institute, Bangkok, Thailand, 1999, 23.

Vahdani, P., Yaghoubi, T., Aminzadeh, Z. (2011). Hospital Acquired Antibiotic-Resistant Acinetobacter Baumannii Infections in a 400-Bed Hospital in Tehran, Iran. Int. J. Prev. Med. 2, 127-130. 


\section{تعريف الميكروب الناشئ Acinetobacter johnsonii وجيناته المقاومة للمضادات الحيوية المرتبطة بوفيات عالية في سمكة البلطي النيلي

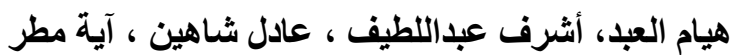

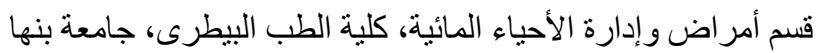

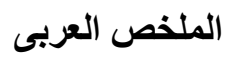

نم التخطيط للار اسة الحالية لاستقصاء العامل المسبب للوفيات الصيفية لسمكة البلطي النيلي

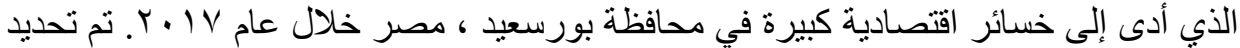

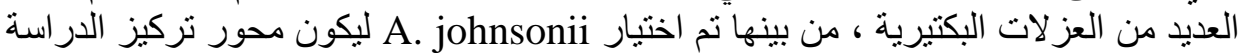

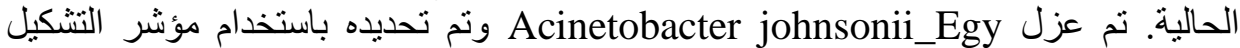

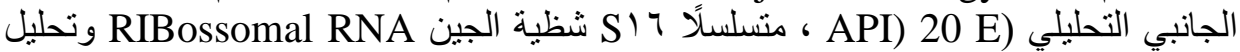

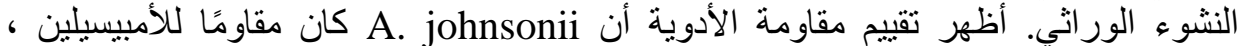

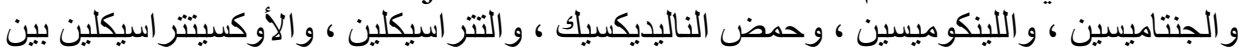

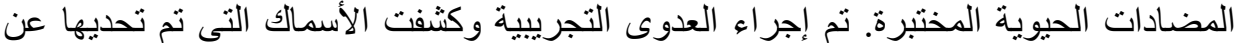

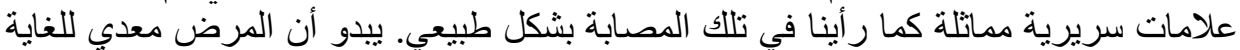

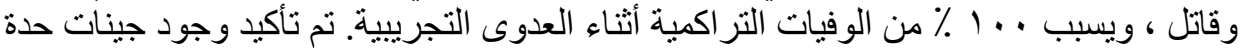

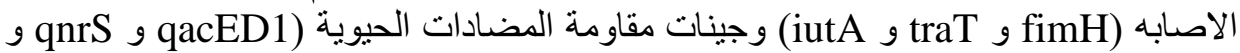

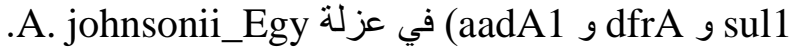

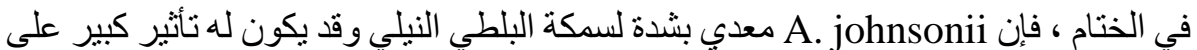

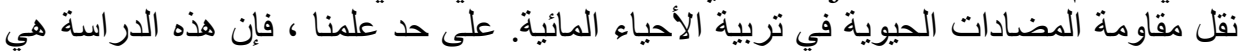

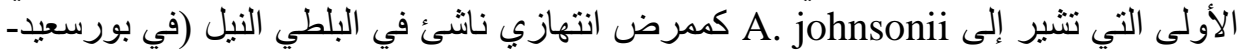

